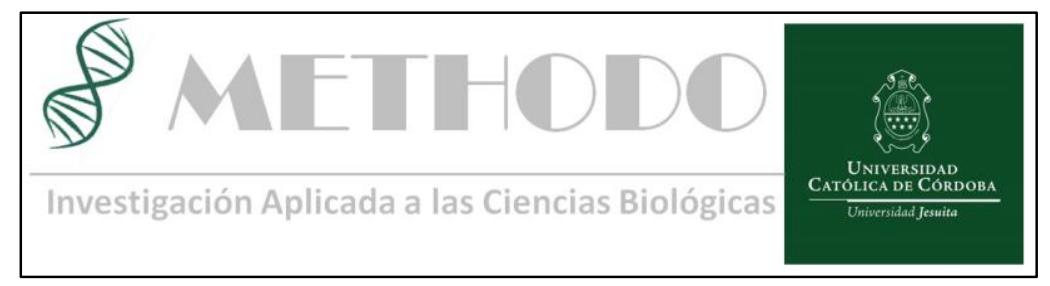

ARTICULO ORIGINAL Methodo 2017;2(4): 114-116

DOI : $10.22529 / \mathrm{me} .2017 .2(4) 03$

Recibido 26 Sep 2017 | Aceptado 20 Nov 2017 | Publicado 30 Dic 2017

\title{
Preservación de restos auditivos en implantes cocleares *
}

\section{Hearing preservation in cochlear implants. *}

*Trabajo Presentado en las XIV Jornadas de Investigación de la Clínica Universitaria Reina FabiolaOctubre de 2017

Sifuentes $\mathrm{D}^{1}$, Labedz L ${ }^{1}$, Romero Orellano $\mathrm{F}^{1}$.

\section{Introducción:}

La implementación de nuevas técnicas quirúrgicas, permitió la preservación de los restos auditivos, así la estimulación no solo sería eléctrica del implante, si no también acústica. ${ }^{1,2}$ La cirugía atraumática permite al colocar el implante coclear, recuperar audición en las frecuencias agudas, que recibirían estimulación eléctrica y, al mismo tiempo, se conservarían las frecuencias graves, que recibirán estimulación acústica otorgada mediante un componente acústico. ${ }^{2-6}$ El objetivo es determinar la preservación auditiva en pacientes que fueron sometidos a implantación coclear. ${ }^{6-8}$

\section{Materiales y Métodos}

Se realizó un estudio retrospectivo descriptivo mediante revisión de historias clínicas de pacientes consecutivos que se sometieron a una implantación coclear entre diciembre 2015 y mayo 2016. Se evaluaron los umbrales de audición previo a la cirugía, A estos mismos se les realiza una evaluación pre implante (T0) en la cual debían presentar en la audiometría previa a la cirugía umbrales auditivos funcionales, que fueron definidos como umbrales en las frecuencias graves $(250 \mathrm{~Hz}$ y $500 \mathrm{~Hz})$ mayores a $85 \mathrm{~dB}$ HL. y al momento del encendido del implante.

Se evaluaron los Umbrales de Audición previo a la cirugía (T0), al momento del encendido del implante (T1) y 3 meses posterior al encendido (T2) en la primera calibración. Se utilizaron para el estudio las frecuencias 125 $\mathrm{Hz}, 250 \mathrm{~Hz}, 500 \mathrm{~Hz}$ y $1 \mathrm{KHz}$.
El encendido del implante se realizó al mes de la cirugía

Previo a la cirugía, se realizó una hora antes, una dosis de antibiótico profilaxis endovenosa, con ceftriaxona, ajustada al peso, a su vez antes del inicio de la misma se realizó una dosis de dexametasona y ácido aminocaproico, ajustada a peso por vía endovenosa. A todos los pacientes se les realizó una incisión retroauricular, una mastoidectomia simple, abordaje a la caja por timpanotomia posterior y apertura del receso facial.

\section{Resultados}

Se evaluaron diez pacientes con restos cocleares funcionales de ambos sexos (5 mujeres y 5 varones), que cumplían los criterios de inclusión y fueron implantados. Estos presentaban un promedio de edad de 13,1 años (con una mediana de 7 años y un rango de 3 a 38 años), el resto de los datos demográficos se encuentran en la Tabla 1. Todos los pacientes previos al implante fueron estimulados con audífonos.

En todos estos pacientes los electrodos se colocaron a través de la ventana redonda, logrando una inserción completa en todos los casos. En $90 \%$ de los pacientes se realizó un fresado sobre la ceja de la ventana redonda para poder exponerla en mejor forma.

El promedio de los umbrales auditivos pre implante fue de $56,5 \mathrm{~dB}$ HL para los $250 \mathrm{~Hz}$; $67,5 \mathrm{~dB}$ HL para los $500 \mathrm{~Hz}$ y $85 \mathrm{~dB}$ HL para los $1 \mathrm{kHz}$, con una media de $69 \mathrm{~dB} \mathrm{HL}$. Al momento del encendido, se obtuvo un 
promedio 66,55dB HL para los $250 \mathrm{~Hz} ; 80 \mathrm{~dB}$ HL para los $500 \mathrm{~Hz}$ y $94 \mathrm{~dB}$ HL para los $1 \mathrm{kHz}$, con una media de 80,1 dB HL. Mediante la comparación de medias, previo a la cirugía y al encendido no se mostraron cambios en los umbrales estadísticamente significativo $(\mathrm{p}>0.05)$.

\section{Conclusiones}

La preservación de los restos auditivos luego de un implante coclear, con técnicas atraumaticas fue posible en el $80 \%$ de los pacientes al momento del encendido del implante.

Se debe tener en cuenta los diferentes factores que favorecen la preservación de estos. Creemos que los dos puntos más importantes son el momento de la inserción del electrodo y la modulación de la inflamación, que es manejada con los corticoides.

Los mecanismos por los cuales luego de una preservación de los restos, al momento del encendido (T1) y primera calibración (T2), en algunos de los casos han descendido no son claros. Sospechamos que los efectos inflamatorios crónicos que generan los propios electrodos, sumado a la excitotoxicidad generada por el implante mismo, pueden ser los responsables de estos.

\section{Introduction:}

The implementation of new surgical techniques allowed the preservation of auditory debris, so the stimulation would not only be electric, but also acoustic., ${ }^{1,2}$ Atraumatic surgery allows the implantation of the cochlear to recover hearing in the frequencies which would receive electrical stimulation and, at the same time, the severe frequencies would be conserved, which will receive acoustic stimulation by means of an acoustic component. ${ }^{2-6}$

The objective is to determine hearing preservation in patients who underwent cochlear implantation. ${ }^{6-8}$

\section{Materials and methods}

A retrospective descriptive study was performed by reviewing the medical records of consecutive patients who underwent cochlear implantation between December 2015 and May 2016. Audit thresholds prior to surgery were evaluated. These patients had a pre-implantation evaluation (T0) in which functional hearing thresholds, which were defined as thresholds in the low frequencies $(250 \mathrm{~Hz}$ and $500 \mathrm{~Hz})$ greater than $85 \mathrm{~dB} \mathrm{HL}$, were to be presented in audiometry prior to surgery. and at the time of implant firing.
Hearing Thresholds prior to surgery (T0), at the time of implant firing (T1) and 3 months after ignition (T2) were evaluated in the first calibration. The frequencies $125 \mathrm{~Hz}, 250 \mathrm{~Hz}$, $500 \mathrm{~Hz}$ and $1 \mathrm{KHz}$ were used for the study. Implant firing was performed one month after surgery

Prior to the surgery, a dose of antibiotic intravenous prophylaxis with ceftriaxone, adjusted for weight, was performed one hour prior, before the start of the surgery, a dose of dexamethasone and aminocaproic acid, adjusted for weight by intravenous route.

All the patients underwent a retroauricular incision, a simple mastoidectomy, approach to the box by posterior tympanotomy and opening of the facial recess.

\section{Results}

Ten patients with functional cochlear remains of both sexes ( 5 women and 5 men), who met the inclusion criteria and were implanted, were evaluated. These patients had a mean age of 13.1 years (median 7 years and a range of 3 to 38 years), the rest of the demographic data are in Table 1. All patients prior to implantation were stimulated with headphones.

In all these patients the electrodes were placed through the round window, achieving a complete insertion in all cases. In $90 \%$ of the patients a milling was performed on the eyebrow of the round window to be able to expose it in better shape.

The mean of the pre-implant hearing thresholds was $56.5 \mathrm{~dB} \mathrm{HL}$ for the $250 \mathrm{~Hz}$; 67.5 dB HL for the $500 \mathrm{~Hz}$ and $85 \mathrm{~dB}$ HL for the $1 \mathrm{kHz}$, with an average of $69 \mathrm{~dB} \mathrm{HL}$. At ignition, an average of $66.55 \mathrm{~dB} \mathrm{HL}$ was obtained for the $250 \mathrm{~Hz} ; 80 \mathrm{~dB}$ HL for the 500 $\mathrm{Hz}$ and $94 \mathrm{~dB} \mathrm{HL}$ for the $1 \mathrm{kHz}$, with a mean of $80.1 \mathrm{~dB}$ HL. By comparing the means, prior to surgery and on ignition, there were no changes in the statistically significant thresholds ( $p>0.05)$.

\section{Conclusions}

The preservation of auditory debris after a cochlear implant with atraumatic techniques was possible in $80 \%$ of the patients at the time of implant firing.

It must take into account the different factors that favor the preservation of these. We believe that the two most important points are the moment of electrode insertion and the modulation of inflammation, which is managed with corticosteroids.

The mechanisms by which after a preservation of the remains, at the moment of ignition (T1) 
and first calibration (T2), in some cases have descended are not clear. We suspect that the chronic inflammatory effects generated by the electrodes, together with the excitotoxicity generated by the implant itself, may be responsible for this.

\section{Bibliografía}

1. Derinsu U, Serin GM, Akdaş F, Batman Ç Cochlear Implantaction: Is hearin: Preservation Necessary in Severe to Profoun Hearing. J Craniofac Surg. 201 Mar;22(2):520-2.

2. Di Nardo W, Cantore I \&quot;Residual hearin: in Cochlear implants patients,\&quot; Eur Arcl Otorhinolaryngol 2007; 855-860.

3. Kiefer J, Gstoettner W, Baumgartner W, Pol SM, Tillein J, Ye Q, von Ilberg C. Conservatiol of low frecuencies hearing in chochlea implantacion. Acta Otolaryngol 2004;124(3):272-80.

4. Sweeney AD, Hunter JB, Carlson ML, Rivas A Bennett ML, Gifford RH, Noble JH, Hayne DS, Labadie RF, Wanna GB. Durability o Hearing Preservation after Cochlea Implantation with Conventional-Lengtl Electrodes and Scala Tympani Insertion Otolaryngol Head Neck Surg 2016;154(5):907-13.

5. Van Abel KM1, Dunn CC, Sladen DP, Olesol JJ, Beatty CW, Neff BA, Hansen M, Gantz BJ Driscoll CL. Hearing preservation amon: patients undergoing cochlear implantation. Oto Neurotol. 2015;36(3):416-21.

6. Santa Maria PL, Gluth MB, Yuan Y, Atlas MD Blevins NH. Hearing preservation surgery fo cochlear implantation: a meta-analysis Oto Neurotol. 2014; 35(10): e256-69

7. Gstoettner WK, van de Heyning P, Connor AF Morera C, Sainz M, Vermeire K, Mcdonald S Cavallé L, Helbig S, Valdecasas JG, Andersor I, Adunka OF. Electric acoustic stimulation o the auditory system: results of a multi-centr investigation. Acta Otolaryngol 2008;128(9):968-75

8. Bruijnzeel $\mathrm{H}$, Draaisma $\mathrm{K}$, van Grootel $\mathrm{R}$ Stegeman I, Topsakal V, Grolman W Systematic Review on Surgical Outcomes anc Hearing Preservation for Cochlear Implantatios in Children and Adults. Otolaryngol Head Necl Surg. 2016;154(4):586-96.

9. Gantz BJ, Turner C, Gfeller KE, Lowder MW Preservation of hearing in cochlear implant surgery: advantages of combined electrical an acoustical speech processing. Laryngoscope. 2005 May;115(5):796-802.

\section{Palabras claves: ESTIMULACION ELECTROACÚSTICA, PRESERVACIÓN AUDITIVA, IMPLANTACIÓN COCLEAR Keywords: ELECTROACOUSTIC STIMULATION, HEARING PRESERVATION, COCHLEAR IMPLANTATION}

\footnotetext{
${ }^{1}$ Servicio de Otorrinolaringología, Clínica Universitaria Reina Fabiola, Universidad Católica de Córdoba, Argentina.

Correspondencia: Daniel Sifuentes. Clínica Universitaria Reina Fabiola. Oncativo 1248 X5004FHP- Córdoba, Argentina. e-mail: dsifuentescock@gmail.com
} 